\title{
STUDI ANALISIS KEBUTUHAN PENGEMBANGAN MEDIA POP UP KEBUDAYAAN BERBASIS AUDIO SEBAGAI PENANAMAN KARAKTER BUDAYA UNTUK SD KELAS 4
}

Endah Istiqomah, ${ }^{(1)}$ Hindun Nur 'Aisyah, ${ }^{(2)}$ Nur Milati ${ }^{(3)}$

Universitas Negeri Yogyakarta ${ }^{(1)(2)(3)}$

DOI : 10.23917/varidika.v31vi2i.10215

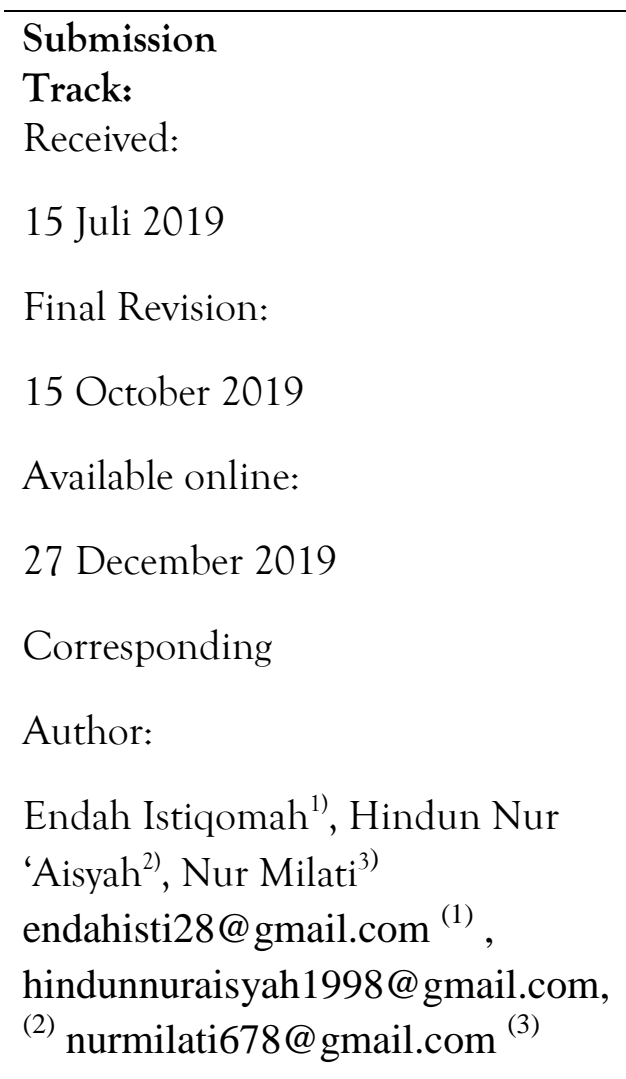

\section{ABSTRACT}

Culture is the identity of a nation, there are more than 633 large ethnic groups in Indonesia (www.bps.go.id). But there have been many Indonesian cultures that have been claimed by other countries. The low understanding of Indonesia's young generation towards culture is one of the problems faced today. Therefore the young generation needs to be reintroduced about its culture. The lack of learning media makes students' motivation in learning culture low. This study aims to: 1) conduct an analysis of the students' lack of interest in Indonesian culture, and 2) see the need for cultural media as planting cultural characters in the 4th grade. This research uses descriptive quantitative method which describes the low awareness of students towards culture. The subject of this study was 4th grade students at SD $N$ Triharjo. Based on the results of media needs, the accumulation of students understanding culture is $31.17 \%$ due to the lack of learning media about culture. The existence of Pop Up media is expected to help teachers in introducing culture among elementary students.

Keywords: Culture; instructional media; pop up; character building; elementary school students

\section{PENDAHULUAN}

Pendidikan menurut UU No 20 tahun 2003 adalah "usaha sadar dan terencana untuk mewujudkan suasana belajar dan proses pembelajaran agar peserta didik secara aktif mengembangkan potensi dirinya untuk memiliki kekuatan spiritual keagamaan, pengendalian diri, kepribadian, kecerdasan, akhlak mulia, serta keterampilan yang diperlukan dirinya, masyarakat, bangsa dan negara." Pendidikan di era digital saat ini sangatlah berkembang pesat, kemajuan dalam bidang teknologi tidak hanya dinikmati oleh orang dewasa saja, anak-anak usia sekolah dasar juga sudah bisa menikmati dari hasil 
perkembangan teknologi saat ini. Dampak positif dari perkembangan teknologi ini sangat dirasakan dalam dunia pendidikan. Namun terdapat juga dampak negatif dari perkembangan IPTEK ini salah satunya adalah melemahnya nilai karakter bangsa (Putri, Dini Palupi: 2018).

Kata "character" berasal dari bahasa Yunani charassein, yang berarti to engrave (melukis, menggambar). Sedangkan dalam Kamus Besar Bahasa Indonesia karakter diartikan tabiat; sifat-sifat kejiwaan, akhlak atau budi pekerti yang membedakan seseorang dengan yang lain; watak. Menurut I.R Pedjawawijatna mengemukakan: "watak atau karakter ialah seluruh aku yang ternyata dalam tindakannya (insani, jadi dengan pilihan) terlibat dalam situasi, jadi memang di bawah pengaruh dari pihak bakat, temperamen, keadaan tubuh, dan lain sebagainya" (Purwanto, 199). Sehingga pendidikan karakter dapat diartikan sebagai pendidikan nilai, pendidikan budi pekerti, pendidikan moral, pendidikan watak, yang bertujuan mengembangkan kemampuan siswa untuk memberikan keputusan baik buruk, memelihara kebaikan, mewujudkan dan menebar kebaikan dalam kehidupan sehari-hari dengan sepenuh hati (Setiawati, Nanda Ayu: 2017). Selain itu menurut Daryanto pendidikan karakter merupakan berbagai usaha yang dilakukan oleh berbagai personil sekolah, bahkan yang dilakukan bersama-sama dengan orang tua dan anggota masyarakat untuk membantu anak-anak dan remaja agar menjadi atau memiliki sifat peduli, berpendirian, dan bertanggung jawab (Daryanto, 2013).

Pendidikan karakter pada intinya bertujuan membentuk bangsa yang tangguh, kompetitif, berakhlak mulia, bermoral, bertoleran, bergotong royong, berjiwa patriotik, berkembang dinamis, berorientasi ilmu pengetahuan dan teknologi yang membantu para siswa membentuk dan membangun karakter mereka dengan nilai-nilai yang baik (Hendriana \& Arnoki : 2016). Salah satu pendidikan karakter yang sedang digencarkan adalah pendidikan karakter berbasis budaya. Hal ini dikarenakan kebudayaan saat ini sudah mulai luntur. Masuknya budaya barat menjadi salah satu pemicu hilangnya budaya bangsa. Kesenian-kesenian daerah seperti ludruk, ketoprak, wayang, gamelan, dan tari menghadapi ancaman serius dari berkembangnya budaya pop khas Barat yang semakin diminati masyarakat karena dianggap lebih modern (Mubah, Safril: 2011).

Berkaitan dengan hal tersebut, pendidikan yang saat ini sedang digencarkan pada kurikulum 2013 yang mana esensi dari kurikulum 2013 adalah tidak hanya bertujuan untuk meningkatkan pengetahuan peserta didik saja, tetapi juga membekali peserta didik dengan keterampilan serta karakter luhur sesuai kepribadian bangsa Indonesia (Shufa Naela: 2018). Namun pada kenyataan dalam pelaksanaannya masih belum maksimal.

SD N Triharjo merupakan salah satu sekolah dasar yang memberikan pendidikan karakter budaya di sekolahnya. Namun berdasarkan wawancara yang dilakukan dengan wakil kepala sekolah, guru kelas, dan beberapa siswa menyatakan bahwa pembelajaran budaya diberikan hanya sebatas materi saja sedangkan siswa belum benar-benar memahami arti dari budaya tersebut. Sehingga perlu adanya sebuah alat bantu untuk membuat siswa memahami pentingnya budaya tersebut. Media pembelajaran adalah suatu cara, alat, atau proses yang digunakan untuk menyampaikan pesan dari sumber pesan kepada penerima pesan yang berlangsung dalam proses pendidikan (Supardi: 2012). Berdasarkan permasalahan tersebut, diperlukan sebuah studi analisis kebutuhan pengembangan media "pop up kebudayaan" berbasis audio sebagai penanaman karakter budaya untuk SD kelas 4 sebagai langkah untuk mengembangkan media guna membentuk karakter cinta budaya. 


\section{METODE PENELITIAN}

Jenis penelitian ini termasuk penelitian deskriptif kuantitatif. Penelitian kuantitatif menurut Sugiyono (2015:13) merupakan penelitian yang berupa angka-angka dan analisis menggunakan statistik. Sedangkan yang dimaksud dengan deskriptif dalam penelitian ini adalah penyajikan data statistik yang bertujuan untuk menggambarkan objek yang diteliti. Subjek penelitian dalam penelitian ini adalah siswa kelas 4 di SDN Triharjo Sleman Yogyakarta. Pemilihan subjek dilakukan secara acak bertujuan untuk memperoleh persebaran data serta tidak terfokus pada karakteristik tertentu pada siswa. Pengumpulan data dalam penelitian ini dilakukan dengan beberapa metode diantaranya:

a. Kuesioner

Kuesioner dilakukan dengan memberikan sejumlah pertanyaan terbuka dan tertutup kepada siswa. Kuesioner dikelompokkan menjadi dua jenis meliputi kebutuhan media dan karakter kebudayaan di SDN Triharjo Sleman Yogyakarta.

b. Wawancara

Wawancara dilakukan secara tidak terstruktur sehingga data yang diperoleh cukup dalam. Wawancara dilakukan kepada 3 narasumber yaitu wakil kepala sekolah, wali kelas 4, dan siswa kelas 4 SD N Triharjo yang terkait budaya dan media apa saja yang biasanya digunakan serta media apa yang diinginkan untuk menjawab tahap analisis kebutuhan.

Guna menyajikan data dan penarikan kesimpulan data dilakukan analisis data dengan menggunakan model analysis interacive model dari Miles dan Huberman (dalam Sugiyono, 2015: 338). Analisis data ini terdiri dari tiga tahapan diantaranya tahap reduksi, penyajian data, dan penarikan kesimpulan. Reduksi data merupakan kegiatan merangkum, memilih hal-hal pokok, memfokuskan pada hal-hal yang penting, dicari tema dan polanya dan membuang yang tidak perlu. Penyajian data dapat dilakukan dalam bentuk uraian singkat, bagan, hubungan antar kategori, flowchart dan sejenisnya. Sedangkan penarikan kesimpulan adalah penarikan kesimpulan akhir mengingat kesimpulan awal masih bersifat sementara, dan akan berubah bila tidak ditemukan bukti-bukti yang kuat yang mendukung pada tahap pengumpulan data berikutnya. Pada sumber data kuesioner penulis menggunakan metode statistik guna mengukur karakter kebudayaan.

\section{HASIL DAN PEMBAHASAN}

\section{Hasil penelitian}

Hasil dari penelitian ini yaitu berupa analisis masalah dan analisis kebutuhan dari permasalahan rendahnya pengetahuan kebudayan di SD N Triharjo Sleman Yogyakarta. Berdasarkan hasil wawancara wali kelas 4 SD dan juga siswa kelas 4 bawah ketertarikan tentang kebudayaan masih kurang, hal tersebut disebabkan karena kurang adanya media yang menarik dan bersifat interaktif.

Terdapat beberapa langkah yang dilakukan oleh peneliti dalam tahap pendefinisian diantaranya:

a) Analisis Awal 
Analisis awal melalui studi literatur dan pengumpulan data awal dimaksudkan untuk mengetahui permasalahan dasar dalam pengembangan media pembelajaran yang mengankat kebudayaan di Indonesia, adapun kebudayaan tersebut diantaranya rumah adat, pakaian, tarian, senjata dan juga makanan. Selain itu media ini berupa pop up berbasis audio dan juga ada konten visual.

b) Analisis peserta didik

Setelah observasi dilakukan tim melakukan pengambilan data kepada siswa dengan menggunakan angket pengetahuan kebudayaan pada siswa kelas 4 SD, diversity terkait gaya belajar siswa dan juga kebutuhan media pada SD N Triharjo khususnya kelas 4.

c) Analisis tugas

Analisis tugas dilakukan untuk mengidentifikasi cara siswa dan peran guru kelas khususnya guru kelas 4 SD dalam memberikan pengetahuan dan mengatasi rendahnya pengetahuan budaya di siswa saat ini. Berdasarkan hasil angket materi kebudayaan didapatkan fakta bahwa sebesar 52\% siswa menyatakan kurang mengetahui kebudayaan Indonesia diantaranya yaitu rumah adat, pakaian, tarian, senjata dan makanan. Hal tersebut dikarenakan kurangnya materi dan cara pembeajaran yang kurang menarik dari guru serta yang paling penting yaitu kurangnya media pembelajaran yang interaktif. Disisi lain, tidak adanya ekstrakulikuler terkait kebudayaan sehingga siswa kurang mengetahui dan memahami kebudayan.

d) Analisis tujuan

Adapun tujuan yang dilakukan untuk menentukan indikator ketercapaian dari media pop up kebudayaan berbasis audio. Pada media pop up kebudayaan berbasis audio ini indikator keberhasilanya yaitu ketika siswa mampu mengetahui beragam kebudayaan di Indonesia ini. Selain itu juga, terbentuknya karakter cinta budaya pada generasi penerus bangsa khusunya siswa kelas 4 SD.

e) Kuesioner

Angket berupa angket terbuka yang sebelumnya telah di validasi oleh dosen pembimbing Ibu Unik Ambarwati, M.Pd. (dosen program studi PGSD Universitas Negeri Yogyakarta).

Tabel 1. Indikator Pengetahuan

\begin{tabular}{|l|l|l|l|}
\hline No & \multicolumn{1}{|c|}{ Indikator } & \multicolumn{1}{|c|}{$\sum$ Skor } & \multicolumn{1}{c|}{$\%$ Skor } \\
\hline 1. & Pengetahuan tentang tarian & 10 & $29,41 \%$ \\
\hline
\end{tabular}




\begin{tabular}{|l|l|l|l|}
\hline 2. & Pengetahuan tentang senjata daerah & 8 & $23,52 \%$ \\
\hline 3. & Pengetahuan tentang makanan daerah & 6 & $17,65 \%$ \\
\hline 4. & Pengetahuan tentang rumah adat & 19 & $55.8 \%$ \\
\hline 5. & Pengetahuan tentang pakaian adat & 10 & $29,41 \%$ \\
\hline
\end{tabular}

Berdasarkan data angket budaya Indonesia yang terdiri dari 33 provinsi di dapat data bahwa pengetahuan tentang kebudayaan yang masih jarang diketahui yaitu pada daerah jawa, Kalimantan, NTB, NTT dan Bali.

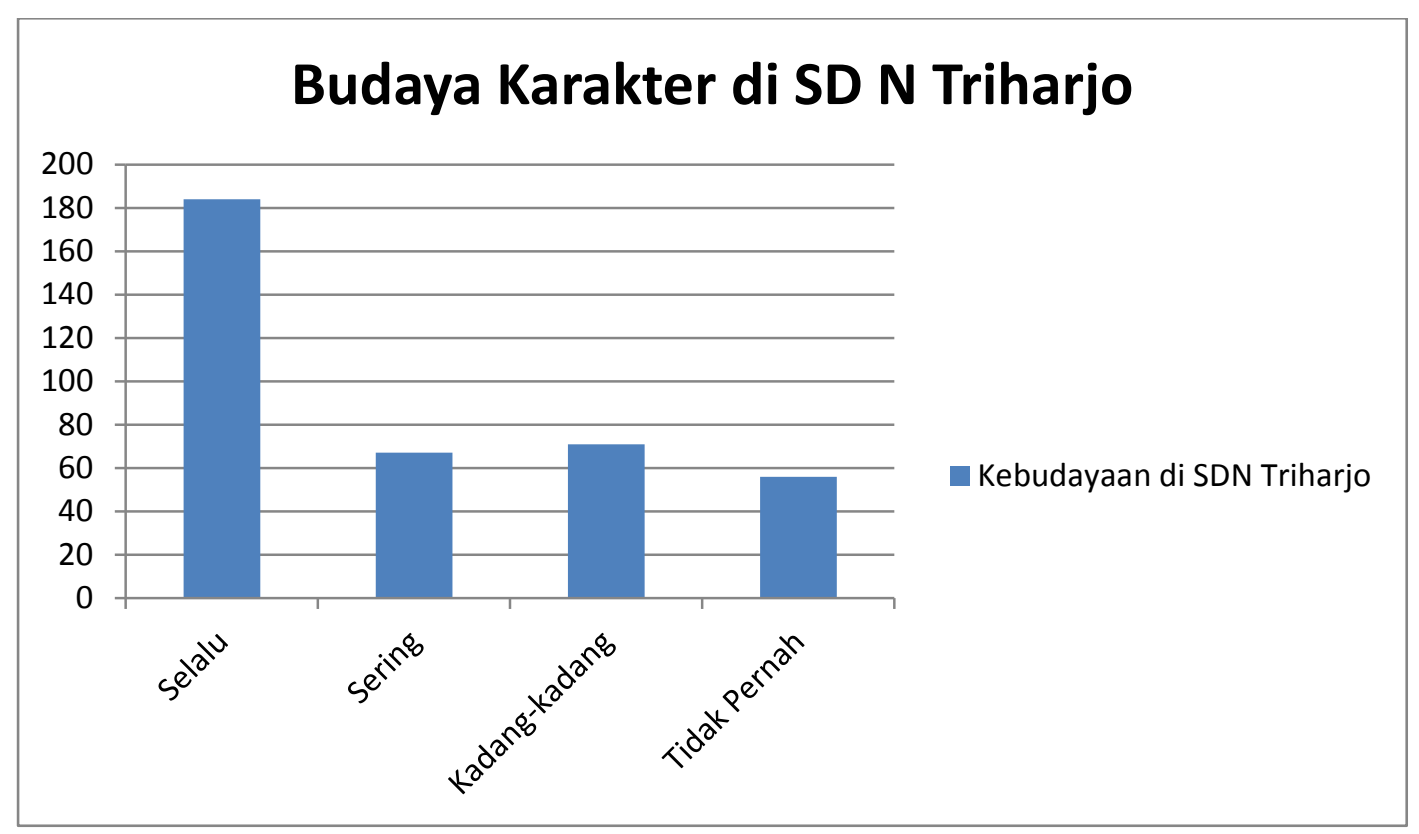

Gambar 1. Angket Budaya di SD N Triharjo

Berdasarkan hasil angket tersebut mencerminkan bahwa kebudayaan di SD tersebut masih belum optimal karena terdapat beberapa siswa yang menyatakan bahwa mereka tidak pernah melakukan budaya yang sedang diterapkan di SD tersebut. 


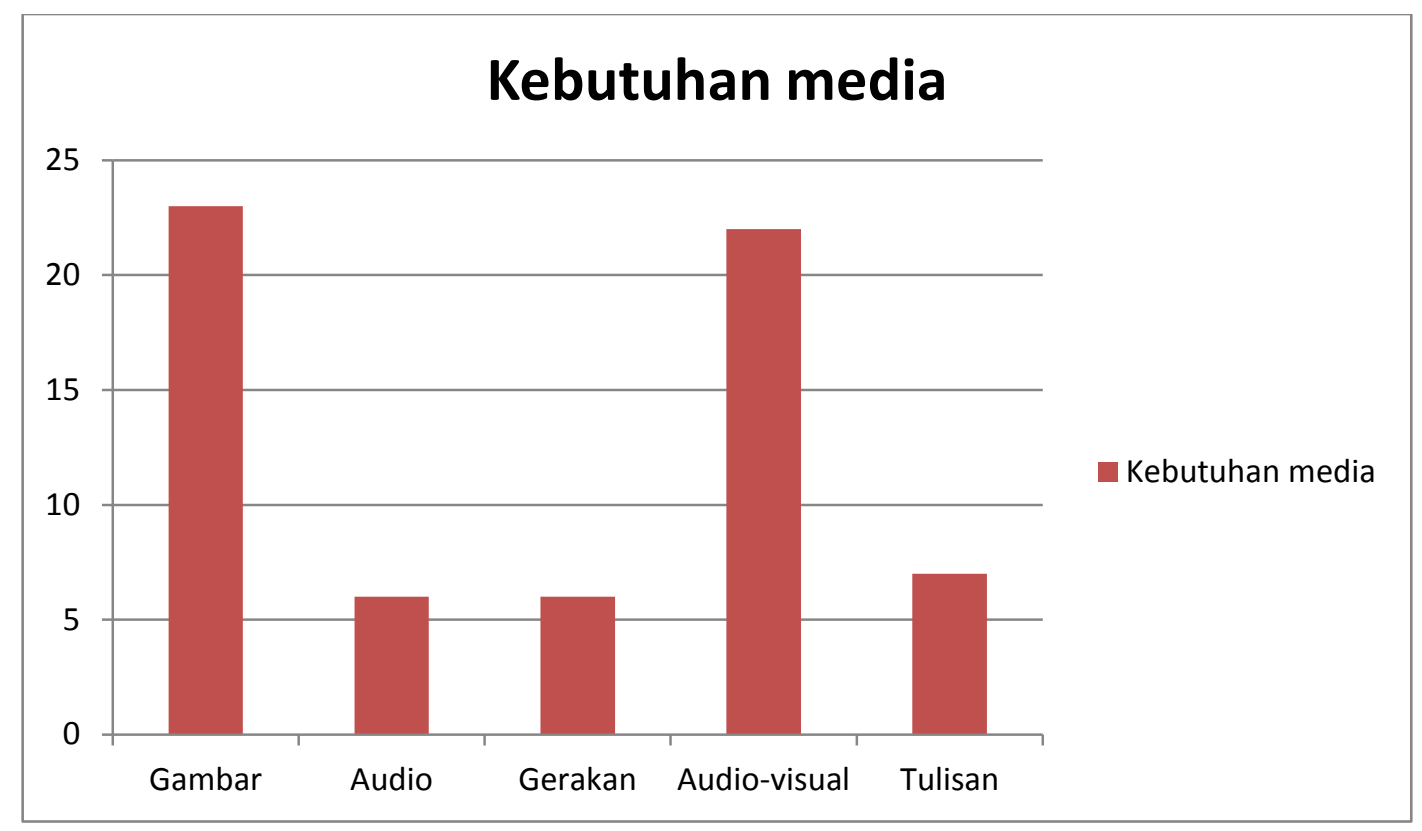

Gambar 2. Kebutuhan media

Berdasarkan hasil analisis tersebut perneliti merancang desain media berupa POP UP Kebudayaan berbasis audio dengan rancangan alat dari sensor LDR sebagai rangkai sumber suara. Sensor LDR ini berfungsi sebagai sensor cahaya untuk menghasilkan sumber suara secara otomatis. Sehingga media ini memuat semua komponen yang dibutuhkan siswa dalam belajar seperti gambar, tulisan, dan audio.

\section{Pembahasan}

Media POP UP Kebudayaan merupakan media pembelajaran POP UP yang berbasis audio dengan sensor cahaya sebagai alat bunyi otomatis. Media ini berisi tentang materi kebudayaan kelas 4. Media ini memenuhi 3 macam gaya belajar yaitu audio, visual, dan kinestetik, karena didalam media ini terdapat tulisan, gambar, audio, dan evaluasi yang dapat digunakan anak untuk bermain sambil belajar. Tujuan dari prinsip bermain sambil belajar adalah untuk menstimulasi otak anak dalam jangka panjang agar dalam memorinya selalu dipenuhi oleh kegiatan-kegiatan yang memberi kesan positif dan tentunya menyenangkan bagi anak (Nurdiani, Yani: 2013). Media pop up juga sangat efektif dalam meningkatkan pengetahuan siswa dari suatu materi. Menurut (Bluemel \& Taylor, 2012) pop-up book ini adalah buku yang memiliki potensi untuk bergerak dan berinteraksi dimana pembuatannya dapat melalui penggunaan kertas sebagai bahan lipatan, gulungan, slide ataupun tab.

Rendahnya pengetahuan siswa mengenai kebudayaan Indonesia merupakan suatu hal yang mengkhawatirkan. Menurut Dyah Satya (2011) menurunnya kecintaan generasi muda terhadap budayanya dapat mengakibatkan nilai nasionalisme yang berkurang terhadap budaya bangsa sendiri dan rasa peduli terhadap masyarakat. Padahal generasi muda adalah penerus masa depan bangsa. Pendidikan karakter adalah 
salah satu langkah untuk menciptakan generasi muda yang cinta budaya. Kurikulum 2013 menyebutkan bahwa tujuan adanya pendidikan adalah pembekalan pendidikan karakter.

Kurangnya perantara untuk memahamkan siswa menjadi salah satu mengapa pembelajaran budaya kurang diminati oleh siswa. Media pembelajaran adalah segala sesuatu yang dapat merangsang terjadi nya proses belajar mengajar (Rohman, 2013: 156). Kurangnya media pembelajaran pada sekolah menjadi penyebab mengapa pembalajaran terlihat kurang menyenangkan dan interaktif. Siswa SD sesuai dengan teori Jean Piaget bahwa siswa SD masih berfikir secara kongkret belum sehingga membutuhkan suatu perantara yang nyata untuk menghantarkan materi dari guru kepada siswa.

Berdasarkan paparan di atas dapat disimpulkan bahwa media POP UP Kebudayaan dibutuhkan dan diperlukan untuk dikembangkan. Rendahnya pengetahuan siswa terhadap budaya menjadi alasan kuat serta kebutuhan media di sekolah dasar yang masih belum optimal. Disisi lain kelebihan dari media ini adalah dapat menanamkan karakter cinta budaya karena dengan model yang audio-visual dan tampilan yang menarik akan lebih membuat siswa untuk tertarik dalam menggunakannya.

\section{SIMPULAN}

Simpulan dari penelitian analisis kebutuhan terkait karakter kebudayaan dan pemahaman kebudayaan pada siswa kelas 4 SD N Triharjo yaitu masih belum sesuai. Berikut hasil data yang diperolah dari analaisi kebutuhan yaitu :

1) Pengetahuan tentang tarian $29,41 \%$

2) Pengetahuan tentang senjata daerah $23,52 \%$

3) Pengetahuan tentang rumah adat $17,65 \%$

4) Pengetahuan tentang pakaian adat $55.8 \%$

5) Pengetahuan tentang pakaian adat $29,41 \%$

Oleh karena itu media ini sangatlah dibutuhkan dalam membantu guru untuk menanamkan karakter cinta budaya pada siswa. Sehingga penanaman karakter budaya lebih optimal. 


\section{DAFTAR PUSTAKA}

Agustin,Dyah Satya Yoga. 2011. Penurunan Rasa Cinta Budaya dan Nasionalisme Generasi Muda Akibat Globalisasi. Jurnal Sosial Humaniora. Vol 4 No. 2

Bluemel, N. L., \& Taylor, R. H. 2012. Pop-up books: A guide for teachers and librarians. California:ABC-CLJO-LLC.

Daryanto dan Suryatri, Darmiatun. 2013. Pendidikan Karakter di Sekolah. Yogyakarta : Gava Media.

Hendriana, Evinna Cinda dan Arnold Jacobus. 2016. Jurnal Pendidikan Dasar Indonesia. "Implementasi Pendidikan Karakter di Sekolah Melalui Keteladanan dan Pembiasaan”. Vol. 1, No 2. Diakses pada tanggal 15 Agustus 2018 21:04

Mubah, Safril. 2011. Strategi Meningkatkan Daya Tahan Budaya Lokal dalam Menghadapi Arus Globalisasi. JOURNAL UNAIR. Vol 24 No 4

Nurdiani, Yani. 2013. Penerapan Prinsip Bermain Sambil Belajar dalam Mengembangkan Multiple Inteligencia Pada Pendidikan Anak Usia Dini. Jurnal EMPOWERMENT. Vol 2 No 2.

Putri , Dini Palupi.2018. Pendidikan Karakter Pada Anak Sekolah Dasar di Era Digital. AR-RIAYAH : Jurnal Pendidikan Dasar vol. 2, no. 1, 2018 STAIN Curup Bengkulu| $\quad \mathrm{p} \quad$ ISSN 2580-362X; $\quad$ e $\quad$ ISSN 2580-3611 http://journal.staincurup.ac.id/index.php/JPD.

Rohman, Muhammad dan Sofan Amri. (2013). Strategi dan Desain Pengembangan Sistem Pembelajaran. Prestasi Pustakaraya. Jakarta.

Setiawati, Nanda Ayu (2017) PENDIDIKAN KARAKTER SEBAGAI PILAR PEMBENTUKAN KARAKTER BANGSA. In: Seminar Nasional Tahunan Pendidikan Ilmu-Ilmu Sosial, 20 Oct 2017, Medan.

Shufa , Naela Khusna Faela. 2018. Pembelajaran Berbasis Kearifan Lokal Di Sekolah Dasar: Sebuah Kerangka Konseptual. Inopendas Jurnal Ilmiah Kependidikan. Vol 1 No 1

Supardi, dkk. 2012. Pengaruh Media Pembelajaran dan Minat Belajar Terhadap Hasil Belajar Fisika. Jurnal Formatif. Vol 2 No 1. 